ТКАЧЕНКО Александр Александрович - доктор экономических наук, профессор; заместитель директора Института исследований международных экономических отношений Финансового университета при Правительстве РФ (125993, Россия, г. Москва, ГСП-3, Ленинградский пр-кт, 49; AATkachenko@fa.ru; ORCID: 0000-0002-8828-1761; Researcher ID: Q-9323-2016; Scopus Author ID: 57218891580; Web of Science Researcher ID: Q-9323-2016; SPIN РИНЦ: 4164-7174)

\title{
ЭКОНОМИКА И ДЕМОГРАФИЯ СОЦИАЛЬНОГО ГОСУДАРСТВА
}

Аннотация. Цель статьи - анализ взаимосвязи основных демографических показателей с экономическим развитием, а также целей и задач, поставленных в принятых документах по росту продолжительности жизни, уровню рождаемости и благосостоянию населения России. Резкое снижение продолжительности жизни в 2020 г. и сокращение финансирования нацпроекта «Здравоохранение» оцениваются как начало нового демографического кризиса на фоне снижения реальных доходов населения, а в 18 субъектах Федерации - даже номинальных доходов. В этой связи поставлено под сомнение сокращение числа бедных в кризисном 2020 г. по данным официальной статистики, сделан вывод о высокой вероятности роста числа бедных и крайне бедных.

Ключевые слова: ожидаемая продолжительность жизни, суммарный коэффициент рождаемости, национальные проекты, здравоохранение, дифференциация доходов, расходы домашних хозяйств

\section{Введение}

Демографическая динамика интересует правительства большинства стран, т.к. она взаимосвязана с экономической динамикой, социально-экономическим развитием страны в целом. Поэтому многие национальные правительства проводят специальную демографическую политику в рамках политики социальной, при этом большое значение имеет выбор политики, которая в XXI в. может быть направлена на поощрение технологических инноваций и институциональных реформ для нейтрализации проблем, связанных с постарением населения, и непосредственно на рост инвестиций в людей любого возраста - от молодых до старых. «При мудрой политике, - отмечает Гита Бхатт, - большее количество из нас будет наслаждаться долгой и хорошей жизнью» [The Long, Good Life: 2]. Международный валютный фонд в 2020 г. посвятил полный мартовский номер журнала Finance \& Development взаимосвязи демографии и экономического благополучия. Выпуск этого номера и его содержание определяются рефреном: демография может определять судьбу страны. В России она несомненно определяется по целому ряду различных причин, что отражается в политике российского государства и в целях, которые оно ставит.

\section{На пороге нового демографического кризиса}

Четверть века назад автор этой статьи задавался вопросом: выходит ли Россия из демографического кризиса в период тяжелых социально-экономических потрясений [Ткаченко 1996], которые позднее были названы системным кризисом. Как утверждал ряд отечественных [Обострение демографического кризиса... 1999; Рыбаковский 2013] и зарубежных [Parfitt 2005] ученых, эта тема была и, к сожалению, остается проблемно-актуальной и широко востребованной [Berman 2017; Вишневский, Щербакова 2018]: от представителей федеральной законодательной и исполнительной власти до руководителей 
регионов, партий, политиков любого направления и СМИ. Демографический кризис позднее описан в нескольких формах ${ }^{1}$ [Ткаченко 2000].

Исследователи и policy-makers обращают внимание на основные факторы демографических изменений: ожидаемую продолжительность жизни, определяемую режимом смертности, уровень рождаемости и миграцию ${ }^{2}$. Эти же факторы были обозначены в принятых концепциях демографического развития (2001) и демографической политики (2007), в ежегодных посланиях президента, в национальных проектах (2018) и, наконец, в национальных целях развития до 2030 года (2020). При этом акцент на ту или иную проблему в этих документах был различным и связанным не только с меняющимся пониманием со стороны государства и общества первоочередности задач, но и с позицией экспертов, разрабатывающих документы, которые, как правило, не проходят общественного обсуждения. Проследим эти изменения на фоне меняющейся ситуации, которая явно обострилась в 2020 г., и не только из-за пандемии COVID-19.

Кризис 1990-х гг. привел к снижению рождаемости в России до самого низкого в истории страны уровня суммарного коэффициента рождаемости $(\mathrm{CKP})^{3}$ 1,157 в 1999 - последнем году многолетнего экономического кризиса. Рост экономики в 2000-2014 гг., несомненно, влиял на одновременный рост СКР до 1,777 - даже выше запланированной в указе 2018 г. вершины повышения рождаемости к 2024 г. в 1,74. Затем динамика роста была прервана рецессией 2014-2016 гг., и в соответствии с лагом в 2016 г. началось новое снижение СКР, а в 2017 г. оно, как отмечает Е. Щербакова, ускорилось, снизившись до 1,504 в 2019 г. [Щербакова 2021]. При этом показатель у сельского населения на 23\% выше, чем у городского.

Показатель ожидаемой продолжительности жизни как целевая установка государства впервые прозвучал в 2018 г. в президентском указе 5 , поставившем цель роста показателя до 78 лет к 2024 г. Затем эта цель в таком же количественном измерении как целевой показатель была отодвинута на 2030 г. 6

По данным Х. Солана, средняя продолжительность жизни во всем мире выросла за 2000-2019 гг. с 67 до 73 лет и с 53 до 63 лет в Африке [Solana 2020], т.е. прирост составил 6 и 10 лет соответственно. За этот же период в России рост этого показателя составил 8,11 года, т.е. был выше среднемирового, но ниже, чем в Африке. При этом рост показателя для мужского населения составил 9,32 года, а для женского - только 6,0 лет. Для выстраивания эффективной политики по решению задачи увеличения ожидаемой продолжительности жизни, которая обозначена как национальная цель, необходимы раздельные показатели для мужского и женского населения, различие между которыми в

1 Демографический кризис. - Демографическая энциклопедия. М.: Энциклопедия. 2013. С. 239-240.

2 Последняя не рассматривается в статье, т.к. тема трудовой миграции и ее роли в экономическом развитии самостоятельна и обширна.

3 Среднее число рождений у одной женщины за всю ее жизнь.

4 Целевое значение по стране на уровне 1,7, как отмечено в рекомендациях Совета Федерации «О ходе реализации национального проекта «Демография», даже ниже, чем он составлял в 2013-2016 гг. Доступ: http://council.gov.ru/activity/activities/ parliamentary/112369/ (проверено 12.11.2021).

5 Указ Президента РФ от 07.05.2018 № 204 «О национальных целях и стратегических задачах развития Российской Федерации на период до 2024 года» (с изм. и доп.). Доступ: https://base.garant.ru/71937200/ (проверено 12.11.2021).

6 Указ Президента РФ от 21.07.2020 № 474 «О национальных целях развития Российской Федерации на период до 2030 года». Доступ: https://www.garant.ru/products/ipo/prime/ doc/74304210/ (проверено 12.11.2021). 
России огромно и названо еще в 1960-х гг. явлением мужской сверхсмертности [Ткаченко 2016: 79] в трудоспособных возрастах. Поэтому и меры должны быть различающимися, а установка на средний, общий для двух полов указатель некорректен $^{1}$, о чем уже не раз говорили специалисты-демографы. К сожалению, это не воспринимается ни экспертами во власти, готовящими постановления, ни многими специалистами из других отраслей знания.

2020 г. «открыл» очередной этап снижения ожидаемой продолжительности жизни населения России, как это уже бывало в 1970-х -начале 1980-х гг. и в первой половине 1990-х гг. ${ }^{2}$ Всего лишь за один год показатель снизился на 1,75 года для мужчин, на 1,74 года для женщин и на 1,8 года для всего населения. Стоит также отметить, что ни один год из периода роста 2000-2019 гг. не давал такого увеличения продолжительности жизни, как было потеряно за 2020 г.: максимальный прирост был в 2007 и 2017 гг. у мужчин - 1,03 года и 1,01 года соответственно и в 2006 г. у женщин - 0,87 года. Меру воздействия в этой потере $C O V I D-19$ и экономической стагнации, включая падение реальных доходов, исследователям еще предстоит выяснить, но финансирование системы здравоохранения в России критикуется уже давно, повсеместно, но не вызывает никаких изменений в бюджетировании этой и других важнейших социальных отраслей, сохраняющих и развивающих человеческий капитал. Стоит также напомнить, что продолжает реализовываться национальный проект «Здравоохранение», на который первоначально планировалось выделить 1 трлн 725,8 млрд руб. до 2024 г., из них 79,2\% - из государственного бюджета и $15,36 \%$ - из бюджетов субъектов федерации. Пропорции на первый взгляд нормальные, если не принимать во внимание, что подавляющее большинство этих субъектов являются дотационными и, соответственно, не имеют достаточных средств. При этом распределение субсидий ${ }^{3}$ на строительство региональных и муниципальных объектов здравоохранения происходило как в рамках реализации этого нового проекта, так и ранее принятой госпрограммы «Развитие здравоохранения». В 2021 г. на этот нацпроект выделено около 255 млрд руб., что на $17 \%$ меньше бюджета нацпроекта в 2020 г. и составляет лишь 33,5\% (в 2020 г. - 43,7\%) нацпроекта «Демография» и 78,2\% $(195,1 \%)$ нацпроекта «Безопасные качественные дороги». Таким образом, судя по этому косвенному признаку, в 2021 г. приоритеты правительства опять сменились, и «Здравоохранение» стало менее приоритетным, чем безопасные дороги. Довольно странное решение на фоне продолжающейся в России и всем мире пандемии и необходимости значительных затрат на защиту здоровья граждан и ликвидацию ее последствий. Обсуждая финансирование национальных проектов, необходимо иметь в виду, что часть выделяемых средств - это прежнее федеральное финансирование на принятые ранее программы.

Необходимо также иметь в виду, что затраты российского государства на здравоохранение осуществляются на фоне очень низких возможностей населения тратить свой доход на оплату сбережения здоровья и явно недостаточных расходов на здравоохранение исходя из принципа социального государства и величины ВВП на душу населения. Это достаточно убедительно видно на рис. 1.

\footnotetext{
1 Тем более, что расчеты по этим трем показателям ведутся Росстатом раздельно, а средний показатель двух полов не равен показателю всего населения.

2 у женского населения этот показатель также падал в 2001-2003 гг.

3 Распоряжение правительства РФ от 31 декабря 2019 года №3265-p. Доступ: http:// government.ru/docs/38747/ (проверено 12.11.2021).
} 


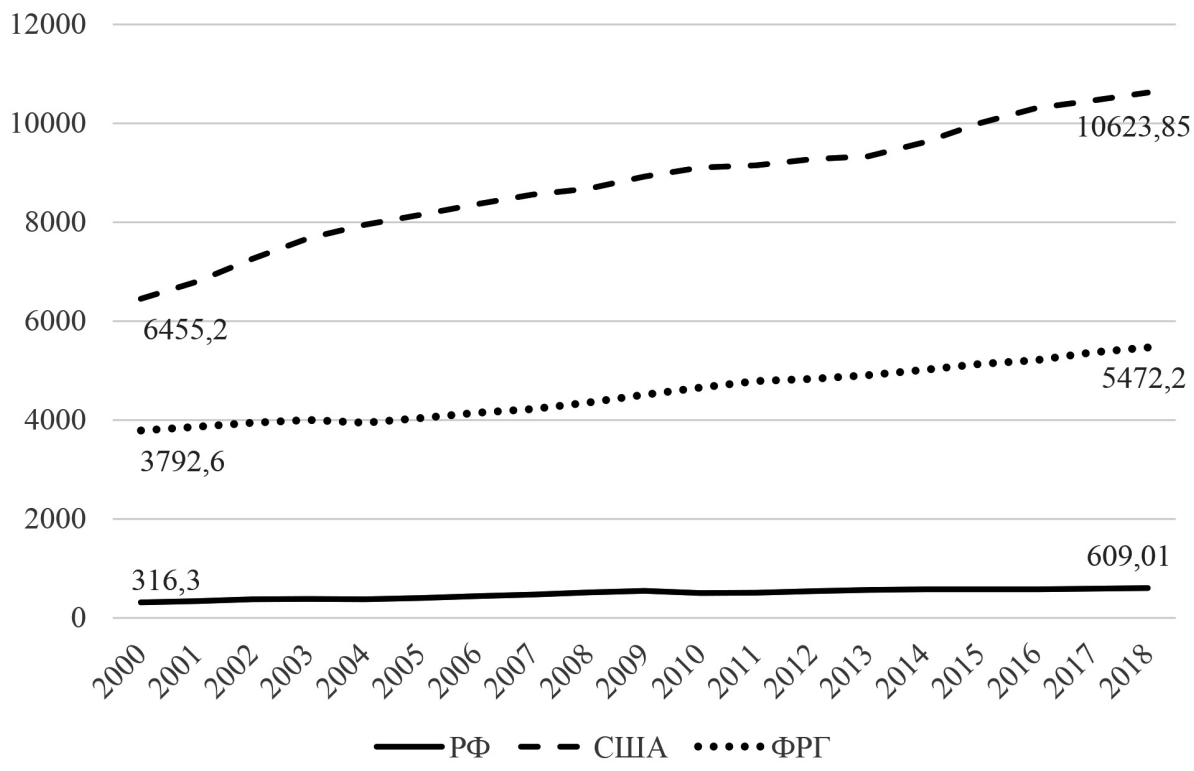

Источник: составлено автором по: https://apps.who.int/nha/database/country_ profile/Index/en

Рисунок 1. Расходы на здравоохранение из всех источников на душу населения в постоянных долларах США (2018)

Хотя рост общих расходов на здравоохранение в расчете на душу населения в РФ был за 2000-2018 гг. выше $(1,93$ раза), чем в США $(1,65)$ или ФРГ $(1,45)$, и это позволило немного сократить разрыв, российские расходы остаются за пределами различий даже в подушевом ВВП. В 2018 г. расходы в России составляли $11,1 \%$ показателя Германия и $5,7 \%$ - США, в то время как соотношение ВВП на душу населения составляло 100: 194: 235 соответственно.

Пандемия COVID-19 заставила увеличить такие расходы даже самые бедные российские домохозяйства. Так, группа домохозяйств с самыми низкими доходами (первая 10-процентная группа с доходом до 7488 руб. в месяц на чел.) тратила в 2019 г. 2,6\% всех своих доходов на здравоохранение, а в 2020 г. уже $3,4 \%$ - это очень значительный рост для самых бедных. Группа самых высокодоходных домохозяйств (10-я группа с доходом 100,8 тыс. руб. в месяц на чел.) тратила, напротив, 3,8\%, а в год начала пандемии, в 2020 г., - только $3,5 \%$. Больше всех тратили высокодоходные домохозяйства 9-й группы (доход 42,8 тыс. руб.): $4,3 \%$ и 5,1\%. Как видим, отрыв самых высокодоходных даже от ближайшей девятой группы очень велик - 2,4 раза. Обратим внимание на динамику доходов россиян и уровень бедности населения, которые не могут не влиять на демографические процессы.

\section{Динамика среднедушевых доходов населения российских регионов}

В 2020 г. произошло уменьшение даже номинальных среднедушевых ежемесячных доходов населения в 18 субъектах РФ: в республиках Северная Осетия - Алания, Башкортостан, Карачаево-Черкесия, Татарстан, в Брянской, Воронежской, Костромской, Липецкой, Московской, Тамбовской, 
Калининградской, Новгородской, Нижегородской, Оренбургской, Свердловской областях, в Ставропольском, Пермском, Алтайском краях. При учете официально объявленного уровня инфляции $(4,91 \%)$ за 2020 г. (хотя низкий уровень индекса цен на потребительские товары и услуги подвергается обоснованным сомнениям не только экспертами, но и самим населением) реальные среднедушевые ежемесячные доходы населения сократились уже в 77 субъектах. Исключение составили следующие 8 субъектов-регионов, где прирост номинальных доходов был выше прироста цен: это республики Калмыкия $(55,3 \%)$, Алтай $(59,5 \%)$ и Тыва $(49,3 \%)$, Саратовская $(66,9 \%)$ и Амурская $(98,0 \%)$ области, Еврейская автономная область $(78,2 \%)$, Чукотский и Ямало-Ненецкий автономные округа. Эти регионы являют собой яркий пример значительной дифференциации доходов между регионами страны, а не только между социально-доходными группами населения. Они образуют две группы: в первой - территории с очень низкими доходами по сравнению со среднероссийскими ${ }^{1}$ - от $49,3 \%$ в Тыве до $66,9 \%$ в Саратовской области и $78,2 \%$ в Еврейской автономной области; во второй группе всего два региона с большой долей населения, приехавшего на заработки: это Ямало-Ненецкий $(246,5 \%)$ и Чукотский $(250,2 \%)$ автономные округа. Таким образом, в регионах, где проживает 96,75\% населения России, в 2020 г. снизились реальные доходы населения ${ }^{2}$, что закономерно в условиях экономического кризиса, вызванного пандемией, но свидетельствует о пассивной роли социального государства. Это падение должно, исходя из экономических закономерностей, вызвать и рост числа и доли бедных, но Росстат утверждает, что число бедных в кризисном 2020 г. снизилось на 300 тыс. чел., а доля бедных сократилась на 0,2 процентных пункта. Реальной картиной социально-экономической жизни страны это не назовешь, а ведь по этой статистической информации российскому правительству следует планировать свою деятельность, в т.ч. и в связи с принятыми обязательствами по ликвидации крайней бедности и уменьшению числа бедных как не только социальной меры [Ткаченко 1999], но и императива экономического развития до 2030 г. Скорее всего, исходя из подобной важности для государственной политики реально и достаточно полно описывающих ситуацию и точных статистических данных, существует Типовой закон об официальной статистике ${ }^{3}$, принятый конференцией европейских статистиков под эгидой Европейской экономической комиссии ООН (2016), по которому основным принципом официальной статистики является профессиональная независимость, означающая, что ее производители принимают свои решения независимо и без какого-либо давления и вмешательства со стороны политических или иных внешних источников ${ }^{4}$. Проблема видится в том, что Росстат в 2018 г. стал даже ведомственным - подчиненным Минэкономразвитию.

Падение реальных доходов в период рецессии 2014-2015 гг. было очень зна-

\footnotetext{
${ }^{1}$ В Амурской области доходы близки, хотя и ниже средних по стране: 98\% в 2020 г. и 94\% в 2019 г.

2 Рассчитано по: https://showdata.gks.ru/report/278930/

3 В качестве рекомендации для стран субрегиона Восточной Европы, Кавказа и Центральной Азии.

4 По разработке, производству, распространению и разъяснению статистики, в т.ч. по выбору используемых источников данных, концепций, определений, методов и классификаций (Типовой закон об официальной статистике, разработанный в рамках проекта девятого транша Счета развития Организации Объединенных Наций (СРООН) для стран Восточной Европы, Кавказа и Центральной Азии. Париж, 27-29 апреля 2016 г. ЕСЕ/ CES/2016/8. Original: English).
} 
чительным в 2014 г., менее значительным - в 2015 г. и продолжилось в 2016 и 2017 гг. В 2018 г. отмечался эфемерный рост, но, по данным Росстата, он составил $101,4 \%$ и почти такой же рост в 2019 г. - 101,7\% (при различии в темпах роста доходов и ИПЦ в эти годы более чем в 3 процентных пункта). Поэтому новое падение в 2020 г. не позволяет говорить, что тенденция роста доходов возобновилась, напротив, доходы населения остаются в состоянии неопределенности, чреватой ростом численности бедного и, может быть, даже крайне бедного (нищего) населения (последнее в соответствии с ЦУР 1 ООН должно быть искоренено к 2030 г.). Влияние экономической рецессии 2014-2015 гг. вполне закономерно и ощутимо: рост более чем на 3 процентных пункта - это более 2 млн чел., оказавшихся в бедности. Но вот обратный процесс снижения показателя в 2016-2020 гг., хотя и замедляющегося, представляется оторванным от реальности, точнее, не коррелирующим с динамикой реальных и даже номинальных доходов населения, т.к. реальные доходы населения в 2017 и 2020 гг. не росли, а уменьшались, что в первую очередь отражается на самых бедных слоях населения [Doorley, Callan, Savage 2021]. Единственная возможность такой динамики - более высокие темпы роста доходов самых бедных (нижние по доходам 10 процентов населения) по сравнению со средними темпами роста, но это для страны с показателем коэффициента Джини выше 0,4 явление маловероятное, т.к. это возможно только в эгалитарных странах (от франц. égalité - равенство), где проводится специальная политика по преимущественному росту доходов населения нижних децилей по сравнению с верхними. Покажем региональный разрез подушевых доходов, выделяя 10 субъектов с самыми высокими (табл. 1) и самыми низкими (табл. 2) доходами.

Следует отметить заметное превышение медианой среднедушевых доходов топ-10 регионов среднероссийского уровня этого показателя, по которому с 2021 г. определяется прожиточный минимум населения. Так, замыкают «десятку» Санкт-Петербург, в котором медиана более чем на треть превышает средний показатель по России, и Республика Саха, где среднедушевой доход выше среднероссийского на 29\%. Кроме представленных в табл. 1 регионов, превышение среднего уровня подушевых доходов в России имеют только 2 региона: Приморский и Хабаровский края с доходами на 4,5\% и 16,8\% выше средних по России. Таким образом, только 12 регионов России имеют более высокий доход, чем среднероссийский показатель, а 73 региона, или $86 \%$ всех субъектов федерации имеют доход ниже среднего, что похоже уже не на дифференциацию территорий, а на их поляризацию: образовались две противоположные группы, сближение которых до обозначенного срока достижения национальных целей в 2030 г. представляется практически невозможным. Еще более удручающе выглядит динамика показателя: в 19 регионах в 2020 г. произошло снижение даже номинального уровня среднедушевых доходов, т.е. абсолютное снижение, чего в социальном государстве быть не должно, и таким регионам необходима своевременная помощь целевыми федеральными трансфертами.

Можно отметить такую положительную тенденцию, как реальный рост среднедушевых доходов в таких бедных республиках России, как Алтай, Тыва, Хакасия, где доходы составляли всего лишь 57\%, $47 \%$ и $64 \%$ среднероссийских (2019 г.), а в 2020 г. поднялись до 60\%, $49 \%$ и 66\% соответственно. А вот динамика доходов в республиках Северного Кавказа, имеющих также значительно более низкие доходы по сравнению со среднероссийскими, имела ярко выраженный негативный характер, т.к. во всех прирост был отрицательным, кроме беднейшей (по доходам) республики страны - Ингушетии, где они выросли даже в реальном измерении, хотя и мизерном $(+0,18)$. Дальневосточный 
Таблица 1

Топ-10 субъектов РФ с наибольшим среднедушевым доходом в 2019 г. (руб. в месяц)*

\begin{tabular}{|c|c|c|c|c|c|c|}
\hline \multirow{3}{*}{ Субъекты РФ } & \multicolumn{3}{|c|}{ Среднедушевой доход } & \multirow{2}{*}{\multicolumn{2}{|c|}{$\begin{array}{c}\text { Соотношение } \\
\text { со средним } \\
\text { показателем по } \\
\text { РФ, \% }\end{array}$}} & \multirow{3}{*}{\begin{tabular}{|c} 
Соотношение \\
величины \\
прожиточного \\
минимума \\
и среднего \\
дохода, \%
\end{tabular}} \\
\hline & \multirow{2}{*}{$\begin{array}{c}\text { всего } \\
\text { населения }\end{array}$} & \multirow{2}{*}{ медианный } & \multirow{2}{*}{ модальный } & & & \\
\hline & & & & медианы & моды & \\
\hline Чукотский АО & 83385,3 & 62682,5 & 35420,9 & 237,8 & 240,2 & 26,6 \\
\hline $\begin{array}{l}\text { Ямало-Ненецкий } \\
\text { АО }\end{array}$ & 83088,0 & 59578,7 & 30633,5 & 226,0 & 207,7 & 19,6 \\
\hline Ненецкий АО & 81040,7 & 58224,4 & 30054,4 & 220,9 & 203,8 & 24,7 \\
\hline г. Москва & 74053,3 & 55004,2 & 30345,9 & 208,6 & 205,8 & 23,2 \\
\hline Магаданская обл. & 65357,2 & 50658,8 & 30435,3 & 192,2 & 206,4 & 30,1 \\
\hline Сахалинская обл. & 59015,2 & 43604,2 & 23804,4 & 165,4 & 161,4 & 25,0 \\
\hline Камчатский край & 52674,4 & 41713,2 & 26158,9 & 158,3 & 177,4 & 38,9 \\
\hline $\begin{array}{l}\text { Ханты- } \\
\text { Мансийский АO }\end{array}$ & 53208,4 & 40568,8 & 23584,0 & 153,9 & 159,9 & 28,3 \\
\hline Московская обл. & 47200,8 & 36307,8 & 21483,3 & 137,7 & 145,7 & 26,9 \\
\hline г. Санкт-Петербург & 47169,3 & 35581,2 & 20246,2 & 135,0 & 137,3 & 24,3 \\
\hline $\begin{array}{l}\text { Республика Саха } \\
\text { (Якутия) }\end{array}$ & 45458,4 & 34313,8 & 19551,4 & 130,2 & 132,6 & 37,8 \\
\hline РФ & 35247,0 & 26363,6 & 14749,2 & 100 & 100 & 30,9 \\
\hline
\end{tabular}

* Примечание: ряд ранжирован по медианному доходу.

Источник: составлено и рассчитано по: https://www.gks.ru/free_doc/new_site/population/ bednost/tabl/tab-bed1-2-6.htm

регион бы единственным в стране, где номинальные доходы населения в 2019 г. не упали, но в Республике Саха (Якутия) они выросли лишь на 0,21\%. Среди субъектов этого региона лишь 4 субъекта федерации из 11 имели и реальный рост доходов в 2019 г. - Забайкальский край, Амурская область, Еврейская автономная область и Чукотский АО. Следует также отметить тот негативный факт, что в 19 республиках Российской Федерации из 21 средний подушевой доход ниже среднего по России. Исключение составляют две республики: Коми, где он практически равен среднероссийскому (на 0,05\% в 2019 и на 1,45\% в 2020 г. выше ${ }^{1}$ ) и Якутия, где показатель выше на 28,6\% в 2019 г. и $27,4 \%$ в 2020 г. ${ }^{2}$

Абсолютная величина прожиточного минимума устанавливается субъектом федерации, и поэтому она закономерно больше в регионах с высокими ценами и с высокой заработной платой (зарплаты с коэффициентом). Но среди топ-10 субъектов с максимальными средними доходами дифференциация, конечно,

${ }^{1}$ В 2021 г. показатель был уже ниже среднероссийского: почти на $11 \%$ в первом квартале и на 1,8\% во втором, но судить по предварительным квартальным данным из-за сезонных выплат довольно рискованно.

2 В Татарстане доход в 2010-е гг. был также выше, в 2020 г. стал ниже на 0,3\%. 
меньше: прожиточный минимум в Ненецком автономном округе (максимум) превышает величину минимума в Санкт-Петербурге (минимум) на 74,6\%, в то время как разрыв между всеми регионами составляет 2,2 раза (превышение максимумом минимума в Республике Мордовия составляет 119,6\%). При этом в таких республиках, как Алтай, Калмыкия, Кабардино-Балкария, КарачаевоЧеркесия, Марий Эл, Мордовия, Чувашия, он не достигает и двух третей среднероссийского показателя, а в Тыве и Ингушетии - даже половины ${ }^{1}$.

Посмотрим на положение населения в самых бедных по среднедушевым доходам субъектах (табл. 2).

Таблица 2

\section{Данные о регионах с самыми низкими среднедушевыми доходами} в Российской Федерации

\begin{tabular}{|c|c|c|c|c|c|}
\hline \multirow{2}{*}{ Субъекты РФ } & \multicolumn{3}{|c|}{$\begin{array}{c}\text { Среднедушевой доход всего } \\
\text { населения (руб. в месяц) }\end{array}$} & \multicolumn{2}{|c|}{$\begin{array}{l}\text { Соотношение* величины } \\
\text { прожиточного минимума, \% }\end{array}$} \\
\hline & 2019 & 2020 & Прирост, \% & $\begin{array}{c}\text { среднего } \\
\text { дохода }\end{array}$ & $\begin{array}{c}\text { модального } \\
\text { дохода }\end{array}$ \\
\hline Республика Ингушетия & 16614 & 16877 & 1,59 & 61,2 & 106,0 \\
\hline Республика Тыва & 16618 & 17629 & 6,09 & 63,7 & 114,3 \\
\hline $\begin{array}{l}\text { Карачаево-Черкесская } \\
\text { Республика }\end{array}$ & 18821 & 18531 & $-1,54$ & 52,6 & 94,0 \\
\hline Республика Калмыкия & 18508 & 19759 & 6,76 & 53,4 & 93,5 \\
\hline Республика Мордовия & 19748 & 20566 & 4,15 & 46,1 & 83,6 \\
\hline Чувашская Республика & 20162 & 21043 & 4,37 & 46,2 & 82,0 \\
\hline Республика Марий Эл & 20864 & 21230 & 1,76 & 45,9 & 89,3 \\
\hline Республика Алтай & 20256 & 21277 & 5,04 & 50,0 & 98,4 \\
\hline Курганская область & 21304 & 21707 & 1,90 & 47,0 & 87,1 \\
\hline $\begin{array}{l}\text { Кабардино-Балкарская } \\
\text { Республика }\end{array}$ & 21474 & 21725 & 1,17 & 53,9 & 95,0 \\
\hline
\end{tabular}

Примечание: ряд ранжирован по возрастанию дохода в 2020 г. -2019 г.

Источник: составлено и рассчитано по: https://www.gks.ru/free_doc/new_site/population/ bednost/tabl/tab-bed1-2-6.htm

Во всех самых низкодоходных регионах страны соотношение величины прожиточного минимума и среднего дохода выше, чем в среднем по России $(30,9 \%)$, но соотношение прожиточного минимума с модальным доходом ${ }^{2}$ показывает, что в Тыве и Ингушетии прожиточный минимум даже выше модального дохода, а еще в трех республиках значения очень близки. Только в четырех субъектах, включая Курганскую обл., средний доход более чем в 2 раза, но ненамного, превышает прожиточный минимум. Все сказанное сви-

\footnotetext{
1 Рассчитано автором по: https://rosstat.gov.ru/folder/13397

2 Наиболее часто встречающаяся в распределении доля, т.е. самая большая доля в рассматриваемой структуре распределения доходов.
} 
детельствует о незавидном положении населения 10 нижних по шкале среднедушевого дохода населения регионов и их праве на первоочередную помощь при проведении государственной политики по искоренению крайней бедности и уменьшению бедности в 2 раза к 2030 г.

Кроме происходившего 5 раз снижения реальных доходов за 2014-2020 гг, в России не улучшается ситуация с расслоением населения по доходам - дифференциация не уменьшается. В странах ОЭСР средний доход самых богатых $10 \%$ населения почти в 9 раз больше, чем у $10 \%$ беднейших (по доходам) слоев населения [OECD 2011: 22], в то время как в России это соотношение колебалось в 2010-е гг. в пределах 15,6-16,6 раз, не показывая тенденцию к снижению. Таким образом дифференциация между $10 \%$ самых высокодоходных российских граждан и $10 \%$ самых низкодоходных была в нашей стране на $79 \%$ выше по сравнению с «клубом» самых богатых стран мира - членов ОЭСР. Если же брать не среднюю среди стран ОЭСР, а страны с сильной социальной политикой ${ }^{1}$ (это сравнение напрашивается, поскольку РФ - социальное государство), то российский показатель будет выше более чем в 4,5 раза $^{2}$. Вопрос о политике сглаживания дифференциации и уменьшения доли бедных, которую проводят все развитые страны независимо от модели развития, например США [Brady, Parolin 2020], и о методах такой политики в России не обсуждается как важная мера государственного регулирования доходов. В последние 30 лет, как показывают А. Аткинсон и Т. Пикетти, доля самых высоких доходов росла в англоязычных странах, Индии и Китае, в отличие от континентальной Европы и Японии. Но симптоматично то, что этот рост был связан в т.ч. с «беспрецедентным ростом доходов от максимальной заработной платы» [Atkinson, Piketty, Saez 2011: 3]. Это явление полностью отсутствует в российской экономике, где быстрый рост заработной платы в самые благоприятные годы подъема наблюдался только в отраслях добывающей индустрии, кроме того, в отличие от европейских стран, в России наблюдался резкий скачок доходов самых высокодоходных групп и их доли в первой половине $1990-$ хг. $^{3}$ и в первом десятилетии XXI в. Затем дифференциация практически остается на том же высоком уровне.

Важным показателем является коэффициент Джини ${ }^{4}$, показывающий меру концентрации доходов или неравномерности их распределения (от 0 до 1). В нашей стране он стал измеряться только в 1991 г., и его величина 0,260 была в пределах социально допустимой нормы. В годы экономического подъема вместе с ростом доходов рос и индекс, показывая усиление неравномерности и, следовательно, большую концентрацию доходов на богатом полюсе и уменьшение доли бедного полюса. Но все же в 2000 г. он был ниже $0,4-0,395$, а к 2010 г. вырос до 0,421, отражая усиление поляризации и уровень социального неравенства. Немного снизившись, индекс в последние годы остается на почти одном и том же уровне - 0,411, отражая отсутствие политики уменьшения концентрации доходов путем их перераспределения 5 . Одним из ярких примеров

\footnotetext{
1 Швеция, ФРГ, Франция, Чехия

2 Рассчитано по: Российский статистический ежегодник. 2020: статистический сборник. М.: Росстат. 2020. С. 161.

3 Например, доля доходов верхних 20\% увеличилась почти в 1,5 раза (к сожалению, данные о доле верхней 10-процентной группы Росстат не публикует). Рассчитано по: 2003. 7.19. Распределение общего объема денежных доходов населения.

4 Дифференциация доходов населения. - Новая российская энциклопедия. М.: Энциклопедия. Т. V(2). 2008. С. 340-341.

5 Имеется в виду налоговая политика, прежде всего предоставление различных налоговых льгот населению с минимальными доходами.
} 
такой политики является Чехия, где коэффициент Джини значительно ниже российского показателя и снижался весь наблюдаемый период XXI в. (см. рис. 2).

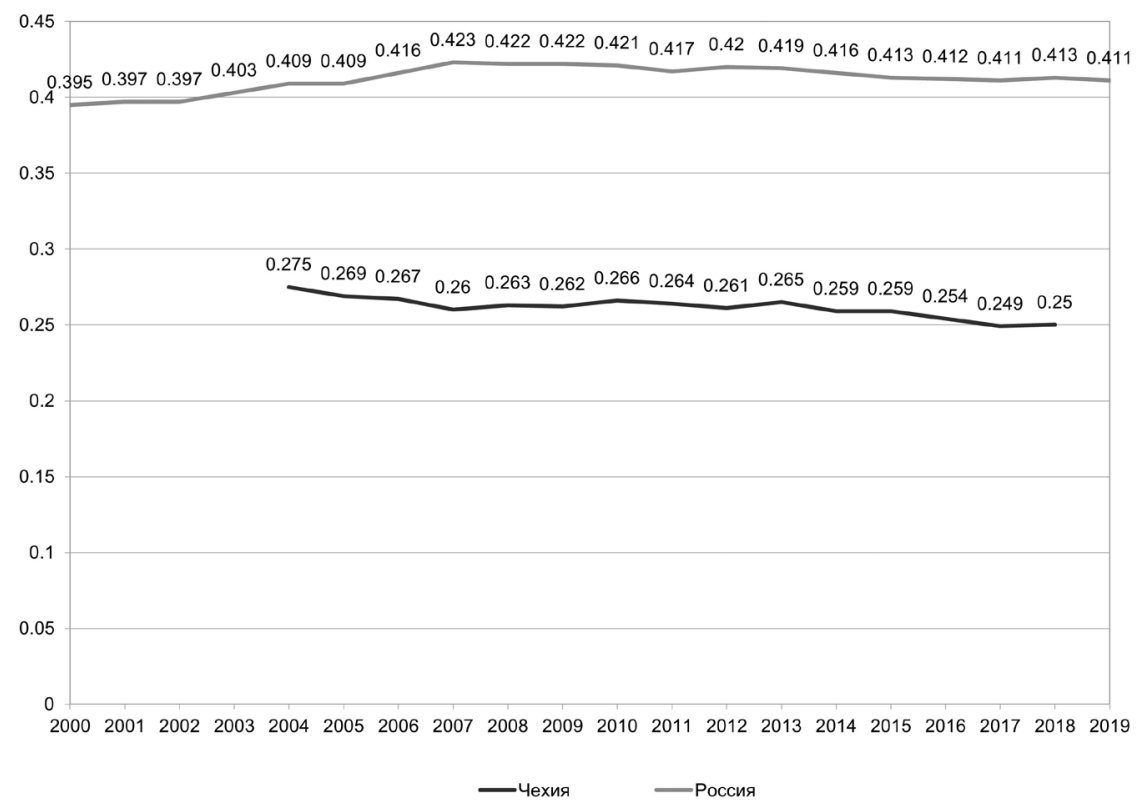

Источник: составлено автором по: Российский статистический ежегодник. 2020: статистический сборник. М.: Росстат. 2020. C. 161; https://stats.oecd.org/Index.aspx?DataSetCode=BLI

\section{Рисунок 2. Динамика коэффициента Джини в России и Чехии}

Анализ ухудшения одного из основных социодемоэкономических показателей - ожидаемой продолжительности жизни показал его зависимость не только от ухудшения эпидемиологической ситуации в связи с пандемией, но и от падения реальных доходов населения, которое неоднократно происходило в 2014-2020 гг. При этом реальный процесс бюджетного наполнения национального проекта «Здравоохранение» отразил фактическую потерю им статуса приоритетного. Возникают сложные вопросы: насколько социально российское государство в проводимой политике, и как оценить социальную политику, проводимую в столь сложных экономических, экологических и иных условиях? Оба вопроса тесно связаны, но позволяет ли отрицательный ответ на один из них положительно оценивать другой?

\section{Список литературы}

Вишневский А.Г., Щербакова Е.М. 2018. Демографические тормоза экономики. - Вопросы экономики. № 6. С. 48-70.

Обострение демографического кризиса и современное положение населения

России (под ред. Б.С. Хорева, Л.В. Иванковой). 1999. М.: Информпечать. 117 с.

Рыбаковский Л.Л. 2013. Факторы депопуляции в России. - Народонаселение. № 3(61). С. 004-019.

Ткаченко А.А. 1996. Выходит ли Россия из демографического кризиса? - Социально-политический жмуннал (Социально-гуманитарные знания). № 5. C. $36-41$. 
Ткаченко А.А. 1999. Бедность как социальный феномен. - Власть. № 9. C. $35-43$.

Ткаченко А.А. 2000. Демографический кризис России. - Власть. № 10. C. 29-36.

Ткаченко А.А. 2016. К 110-летию со дня рождения Б.Ц. Урланиса. - Bonросы статистики. № 7. С. 73-81.

Щербакова Е.M. 2021. Демографические итоги I полугодия 2021 года в России (часть I). - Демоскоn Weekly. № 911-912. Доступ: http://demoscope.ru/ weekly/2021/0911/barom01.php (проверено 12.11.2021).

Atkinson A.B., Piketty T., Saez E. 2011. Top Incomes in the Long Run of History. Journal of Economic Literature. Vol. 49. No. 1. P. 3-71.

Berman I. 2017. Russia's Fraught Demographic Future. - Russia in Decline. The Jamestown Foundation. 200 p. URL: https://www.ilanberman.com/19487/russiafraught-demographic-future (accessed 12.11.2021).

Brady D., Parolin Z. 2020. The Levels and Trends in Deep and Extreme Poverty in the United States, 1993-2016. - Demography. Vol. 57. Is. 6. P. 2337-2360.

Doorley K., Callan T., Savage M. 2021. What Drove Income Inequality in EU Crisis

Countries during the Great Recession? - Fiscal Studies. Vol. 42. Is. 2. P. 319-343.

OECD (2011). Divided We Stand: Why Inequality Keeps Rising. OECD Publishing. 388 p. URL: https://doi.org/10.1787/9789264119536-en

Parfitt T. 2005. Russia's Population Crisis. - The Lancet. Vol. 365. No. 9461. P. 743-744.

Solana J. 2020. Putting the Twenty-First Century Back on Track. - Project Syndicate. URL: https://www.project-syndicate.org/commentary/new-course-for-world-aftercovid-19-by-javier-solana-2020-12 (accessed 12.11.2021).

The Long, Good Life. Demographics and Economic Well-Being. - Finance \& Development. 2020. Vol. 57. No. 1. 64 p. A Quarterly Publication of the International Monetary Fund. URL: https://www.imf.org/external/pubs/ft/fandd/2020/03/pdf/ fd0320.pdf (accessed 12.11.2021).

TKACHENKO Alexander Alexandrovich, Dr.Sci. (Econ.), Professor; Deputy Director of the Institute for Research of International Economic Relations, Financial University under the Government of the Russian Federation (49 Leningradsky Ave, GSP-3, Moscow, Russia, 125993; alaltkachenko@gmail.com)

\section{ECONOMY AND DEMOGRAPHY OF A SOCIAL STATE}

\footnotetext{
Abstract. The main purpose of the article is to analyze the relationship between the main demographic indicators and economic development. A retrospective analysis of national goals and objectives set in official documents on the growth of life expectancy, the total fertility rate and the well-being of the population is also carried out. A sharp decline in life expectancy in 2020 and a reduction in funding for the national project "Health" are assessed as the beginning of a new demographic crisis in Russia, which occurs along with another decrease in real incomes of the population, and in eighteen constituent regions of the Russian Federation, even with a decrease in nominal incomes. Analyzing the dynamics of per capita incomes in Russian regions, the author concludes about their polarization, since $86 \%$ of regions have incomes below the national average. The article also includes the fact that in 19 national republics of the Russian Federation out of 21, the average per capita income is lower than the average for Russia as a clearly negative characteristic of the regional level of income. The dynamics of incomes in the republics of the North Caucasus, with the exception of Ingushetia, had a particularly expressed negative character. In this regard, the decline in the number of poor people in the crisis year of 2020 was questioned according to official statistics, and the author concludes that there is a high likelihood of an increase in poverty and extreme poverty in the near future.

Keywords: life expectancy, total fertility rate, national projects, health care, income differentiation, household expenditures
} 